\title{
First lactation ovarian function in dairy heifers in relation to prepubertal metabolic profiles
}

\author{
V J Taylor, D E Beever ${ }^{1}$, M J Bryant ${ }^{1}$ and D C Wathes \\ Department of Veterinary Basic Sciences, Royal Veterinary College, University of London, Hatfield AL9 7TA, UK \\ ${ }^{1}$ Department of Agriculture, University of Reading, Reading RG6 6AT, UK \\ (Requests for offprints should be addressed to D C Wathes, Reproduction and Development Group, Royal Veterinary College, Hawkshead Lane, \\ North Mymms, Hatfield, Hertfordshire AL9 7TA, UK; Email: dcwathes@rvc.ac.uk)
}

\begin{abstract}
The aim of this study was to determine whether any differences in the GH-IGF-I axis in juvenile calves were predictive of fertility problems as adult cows. Endogenous metabolic hormone profiles before and after feeding and the response to a GH-releasing factor (GRF) challenge were measured in prepubertal (6 month) dairy calves. These metabolic parameters were subsequently related to physical characteristics at puberty and to ovarian function during the first lactation. Milk progesterone analysis was used to categorize the animals into those with normal progesterone profiles following calving $(n=17)$ and those that developed delayed ovulation (DOV1, $n=9)$ or persistent corpus luteum (PCL1, $n=6$ ) profiles. There were associations between prepubertal GH parameters, glucose and non-esterified fatty acid (NEFA) concentrations and the body condition score at which the animals attained puberty. The calves which subsequently developed DOV1 profiles as cows tended to have a higher GH pulse amplitude during fasting than normal profile animals, they did not show the anticipated decrease in circulating glucose concentrations following a post-
\end{abstract}

prandial rise in insulin and they also had the lowest IGF-I concentrations. The calves that later developed PCL1 had a significantly larger GH pulse amplitude and pulse area than normal profile animals in the fed period and had the highest IGF-I concentrations. There were no differences in prepubertal insulin or NEFA concentrations or in the $\mathrm{GH}$ response to a GRF challenge between the different progesterone profile categories. Plasma IGF-I concentrations in prepubertal animals were positively correlated with their post-calving concentrations, whereas glucose concentrations had a negative correlation between these time-periods. These results suggested that the different juvenile endocrine profiles of the DOV1 cows may predispose them to a higher rate of tissue mobilization during lactation and a consequent reduction in fertility, while altered GH and IGF-I levels in PCL1 cows may later contribute to the maintenance of the persistent corpus luteum. Therefore metabolic differences in prepubertal calves were later reflected by altered reproductive function during the first lactation.

Journal of Endocrinology (2004) 180, 63-75

\section{Introduction}

Some modern dairy cows are capable of producing high milk yields whilst remaining fertile whereas others develop ovarian disturbances and fertility problems. Genetic selection for increased milk yield has altered the somatotrophic axis (growth hormone $(\mathrm{GH})$, insulin and insulin-like growth factors (IGFs)), with increased circulating concentrations of $\mathrm{GH}$ associated with greater milk yield in lactating dairy cows (Bonczek et al. 1988, Lukes et al. 1989). GH receptor binding in the liver results in synthesis and secretion of IGF-I into the circulation where it is responsible for many of the growth-promoting actions of GH (LeRoith et al. 2001).

The GH-IGF-I axis in the female dairy calf is of key importance in growth, reproduction and lactation (Gluckman et al. 1987, Chase et al. 1998). The partitioning of nutrients into these processes is affected by the endogenous $\mathrm{GH}$ rhythm, including the post-feeding $\mathrm{GH}$ response and the stimulation of hepatic IGF-I production. These, in turn, are regulated by complex feedback mechanisms involving insulin, glucose, fatty acids and other metabolites (Etherton \& Bauman 1998, Chilliard 1999). Following birth, the GH-IGF axis in dairy calves is functional but feedback mechanisms are still developing. GH concentrations decrease post-puberty (Govoni et al. 2002) and the response to GH-releasing factor (GRF) decreases (Lapierre et al. 1992). A further complication is that the relationship between GH and IGF-I uncouples in physiological states of compromised nutrition or disease so that concentrations of IGF-I do not increase, as expected, despite increases in GH (GH resistance; Thissen et al. 1994, Van den Berghe et al. 1998). This situation also occurs in dairy cows at the start of lactation (McGuire et al. 1995a). 
Table 1 Physical characteristics of the heifers at different ages (means \pm S.E.M., $n=32$ )

\begin{tabular}{|c|c|c|c|c|}
\hline & $\begin{array}{l}\text { Day of GRF } \\
\text { challenge }\end{array}$ & Puberty & $\begin{array}{l}\text { First } \\
\text { conception }\end{array}$ & $\begin{array}{l}\text { First } \\
\text { calving }\end{array}$ \\
\hline \multicolumn{5}{|l|}{ Characteristic } \\
\hline Age (days) & $176 \pm 2 \cdot 6$ & $284 \pm 6 \cdot 0$ & $431 \pm 4 \cdot 9$ & $708 \pm 5 \cdot 1$ \\
\hline Body weight (kg) & $186 \pm 2 \cdot 4$ & $261 \pm 4 \cdot 8$ & $381 \pm 6 \cdot 1$ & $524 \pm 8 \cdot 9$ \\
\hline Body condition score $(1-5)$ & $2 \cdot 5 \pm 0 \cdot 04$ & $1 \cdot 9 \pm 0.09$ & $3 \cdot 2 \pm 0 \cdot 10$ & $2 \cdot 8 \pm 0 \cdot 06$ \\
\hline
\end{tabular}

Metabolic hormones are also important regulators of many aspects of reproductive function. Feedback of insulin and IGF-I acts at the pituitary level to alter luteinizing hormone (LH) pulsatility and responsiveness (Adam et al. 2000). Type 1 IGF receptors have been identified in different sized bovine follicles and in corpora lutea (Perks et al. 1999), and in ovarian tissues of numerous species IGF-I stimulates granulosa and luteal cell mitogenesis in vitro and amplifies gonadotrophin action (Spicer \& Echterncamp 1995, Webb et al. 1999). In ruminants, the majority of follicular fluid IGF-I is derived from the circulation (Leeuwenberg et al. 1996), hence the availability of IGF-I to follicles is reduced when plasma levels are low (e.g. nutritional restriction; Schoppee et al. 1996). This may result in a failure of the dominant follicle to ovulate in the early post-partum period (Beam \& Butler 1999). Insulin can also stimulate granulosa cell proliferation, enhance follicle-stimulating hormone-induced oestradiol production in vitro (McArdle et al. 1991, Spicer \& Echterncamp 1995) and increase progesterone production (Staples et al. 1998). GH also has important actions on folliculogenesis and luteal function, at least some of which are independent of the intermediate actions of IGF-I (Wathes et al. 1995, Lucy et al. 1999, Childs 2000).

Studies in both the USA (Butler \& Smith 1989) and the UK (Lamming et al. 1998) have shown that there has been a significant decline in dairy cow fertility over the past 30 years. As this has been temporally associated with genetic selection for increased yield, it is likely that the two trends are related. Previous studies using secretagogue challenges found that the release of $\mathrm{GH}$ was related to genetic potential for milk yield in dairy calves (Løvendahl et al. 1991a) and in lactating beef cows (Auchtung et al. 2001). We reasoned that hormone profiles or GH secretagogue challenges may also reveal differences between dairy animals likely to be fertile or to develop reproductive problems. Milk progesterone analysis (Bulman \& Lamming 1978) allows non-invasive monitoring of reproductive activity in dairy cows and has revealed that many dairy cows have abnormal progesterone profiles which contribute to significantly poorer fertility parameters (Lamming et al. 1998, Royal et al. 2000, Taylor et al. 2003). Any hormone or metabolic differences found in prepubertal heifers that related to subsequent ovarian function could be used to identify replacement heifers capable of producing high milk yields and remaining fertile.
The aims of the study presented here were, therefore, to investigate the endogenous metabolic hormones and response to a $\mathrm{GH}$ secretagogue challenge in prepubertal female dairy calves as predictors of their ovarian function. Actual reproductive function in the first lactation of the same cows was used to analyse the hormone and metabolite data obtained from a prepubertal serial bleed and GRF challenge.

\section{Materials and Methods}

\section{Animals and housing}

All experiments were performed under the UK Animals (Scientific Procedures) Act, 1986 and animals were treated in accordance with UFAW and FRAME guidelines. Thirty-two Holstein-Friesian female dairy calves of approximately 6 months of age were included in this study. They were group housed on straw in a wellventilated barn and fed a diet of maize silage ad libitum, $1.5 \mathrm{~kg}$ maize gluten and $1.5 \mathrm{~kg}$ calf pellets (Supercalf Starter Pellets; Lloyds, Oswestry, Shropshire, UK; energy content $12.95 \mathrm{MJ}$ per kg dry matter, $18 \%$ crude protein) per animal per day. Water was available ad libitum.

\section{Prepubertal serial bleed and GRF challenge}

At approximately 6 months of age (Table 1), a 10-h metabolic profile was obtained from each prepubertal calf, including a challenge with GRF. The 6 month age point was chosen to obtain the optimal response to the GRF challenge between early development and pubertal changes (Shingu et al. 2001). Ovarian follicular development was examined the day before the GRF challenge by transrectal ultrasonography using an Aloka SSD-500 portable, real-time B-mode, two-dimensional ultrasound scanner (BCF Technology, Livingston, Scotland, UK) with a stiffened $7 \cdot 5 \mathrm{MHz}$ linear array transducer. This confirmed that the calves were all prepubertal. Following the challenge, the calves were subsequently blood sampled twice weekly until they reached puberty. This was based on the time of first ovulation from plasma progesterone measurements (see Table 1).

For the serial bleed, an indwelling jugular venous cannula (14 gauge infusion set; Vygon, Cirencester, Glos, 
UK) was inserted under local anaesthesia (2 $\mathrm{ml}$ xylocaine (2\%) s.c.) on the previous day. The catheters were flushed with $2 \mathrm{ml}$ heparin saline $(250$ units heparin $/ \mathrm{ml}$ saline $+300 \mathrm{mg}$ crystapen antibiotic $/ 500 \mathrm{ml}$; National Veterinary Supplies, Fenton, Stoke-on-Trent, UK) and the patent end of the catheter tube was fitted with a three-way tap (Vygon). On the day of sampling, the calves were fed at $1200 \mathrm{~h}$ (normal feed time was $1000 \mathrm{~h}$ ) and the food remaining was removed at $1500 \mathrm{~h}$ and returned at the end of the session at $1800 \mathrm{~h}$. Water was freely available at all times.

Blood was sampled through the cannulae every $15 \mathrm{~min}$ through the day during a serial bleed from $0800 \mathrm{~h}$ until $1800 \mathrm{~h}$ for measurement of GH. Bovine GRF (bGRF (1-44); Bachem, Saffron Walden, Essex, UK; $0 \cdot 2 \mu \mathrm{g}$ per $\mathrm{kg}$ liveweight (Løvendahl et al. 1991b)) was administered i.v. in a bolus through the cannula at $1600 \mathrm{~h}$. Sterile water was used to dissolve the GRF and the injection volumes varied according to the body weights of the individual calves but each injection was less than $5 \mathrm{ml}$. Sampling frequency was increased so that blood samples for $\mathrm{GH}$ measurement were taken at $-15,-5,5,10,15,20,30$, $45,60,75,90,105$ and $120 \mathrm{~min}$ relative to the GRF challenge.

Blood samples were collected into heparinized tubes onto ice, centrifuged at $2000 \mathrm{~g}$ at $4{ }^{\circ} \mathrm{C}$ for $15 \mathrm{~min}$, and the plasma was stored at $-20^{\circ} \mathrm{C}$ until assayed. On the following morning a final blood sample was taken after the serial bleed and the cannulae were removed.

$\mathrm{GH}$ was measured in all samples. Insulin concentrations were measured in five samples, glucose and non-esterified fatty acids (NEFA) in six samples and IGF-I in three samples from the serial bleed and in the sample taken on the second day. The time-points were chosen to reflect the diurnal variation as determined from more frequent analyses of samples obtained from between three and ten calves, depending on the hormone or metabolite measured.

\section{First lactation reproductive and metabolic profiling}

The maiden heifers were served by artificial insemination at observed oestrus to achieve first conception at approximately 14 months of age. Further fertility details have been published elsewhere (Taylor et al. 2003). Pregnant heifers were fed a transition diet from 4 weeks prior to calving. The animals calved at approximately 2 years of age (Table 1). Following calving, the first lactation cows were managed indoors in loose stalls in the same yard and fed a total mixed ration (TMR) ad libitum. Water and a mineral salt lick were freely available. Daily subsamples of transition diet and lactating TMR, concentrates and forages were combined into separate weekly samples and submitted for routine feed analysis. Details of the first lactation diets have been published separately (Taylor et al. 2003). The cows were milked three times per day and parlour measurements of yield were automatically recorded at each milking.

\section{Progesterone profile categories}

Milk samples were collected three times per week. The progesterone profiles of the individual cows were categorized into normal (Fig. 1A) and two types of abnormal patterns of ovarian activity (Fig. 1B and C; after Bulman \& Wood 1980, Lamming \& Darwash 1998). Normal cycles were characterized by milk progesterone concentrations of greater than $3 \mathrm{ng} / \mathrm{ml}$ within 45 days post partum and regular cycles thereafter with luteal phases of up to 19 days and interluteal phases of less than 12 days. Delayed ovulation type 1 (DOV1) occurred in the immediate post-calving period when progesterone concentrations were less than $3 \mathrm{ng} / \mathrm{ml}$ for at least 45 days post partum (Fig. 1B). Persistent corpus luteum type 1 (PCL1) occurred in the immediate post-calving period, when progesterone concentrations were greater than $3 \mathrm{ng} / \mathrm{ml}$ for at least 19 days during the first cycle post partum (Fig. 1C). Cows with other categories of abnormal profile were not included in this study as the numbers were insufficient for further investigation.

\section{Hormone and metabolite assays}

Plasma samples were assayed for GH using a modified form of the double-antibody radioimmunoassay of Hart et al. (1975). Standards and tracer used were highly purified bGH (AFP-11182B, a kind gift from Dr A F Parlow, NHPP, USA). Radioiodination was by the chloramine-T method. Briefly, the assay used a guinea-pig bGH antibody (a kind gift from Dr P Løvendahl, Foulum, Tjele, Denmark) and separation was by donkey anti-guinea-pig SAC-CEL second antibody (Immunodiagnostic Systems Ltd, Boldon, Tyne \& Wear, UK). Serial dilution of calf plasma with buffer paralleled the standard curve. The inter- and intra-assay coefficients of variation were $12 \cdot 2 \%$ and $7 \cdot 6 \%$ respectively. The sensitivity was $2 \cdot 6 \mathrm{ng} / \mathrm{ml}$.

IGF-I concentration in plasma was analysed after ethanol-acetone-acetic acid extraction of IGF-I-binding proteins according to the method of Osgerby et al. (2002) using a double-antibody radioimmunoassay validated in our laboratory. Serial dilution of calf plasma with buffer paralleled the standard curve. The inter- and intra-assay coefficients of variation were $11 \cdot 2 \%$ and $6 \cdot 7 \%$ respectively.

Plasma insulin was measured by bovine enzyme-linked immunosorbent assay plate kits (DRG Diagnostics; Immunodiagnostic Systems Ltd, Marburg, Germany). The assay sensitivity was $0 \cdot 20 \mathrm{ng} / \mathrm{ml}$. The inter- and intra-assay coefficients of variation were $8.9 \%$ and $9 \cdot 4 \%$ respectively.

Plasma glucose and NEFA concentrations were measured using a COBAS MIRA automated analyser (Roche) using enzymatic kits: an endpoint method for 
A

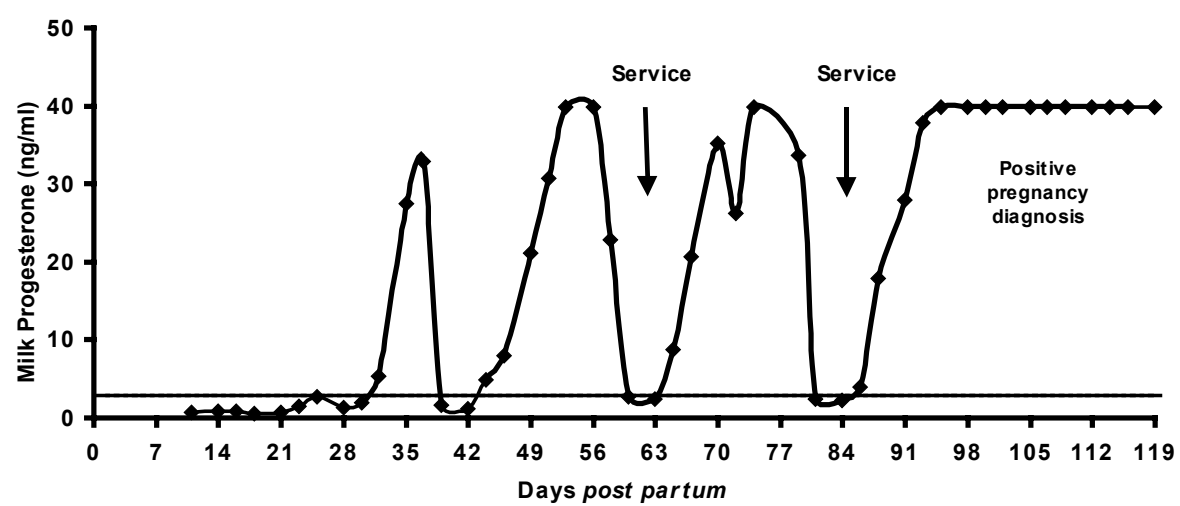

B

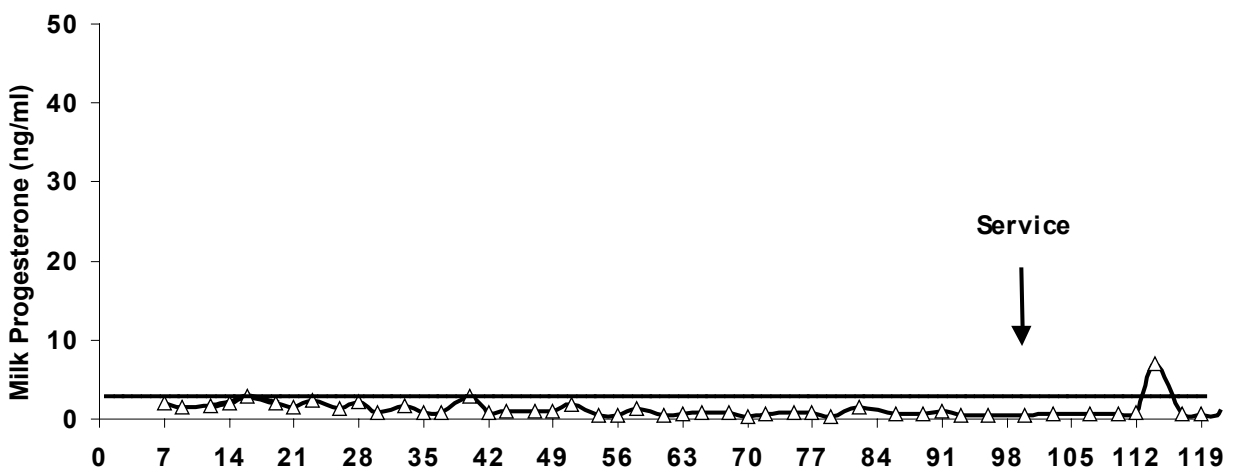

C

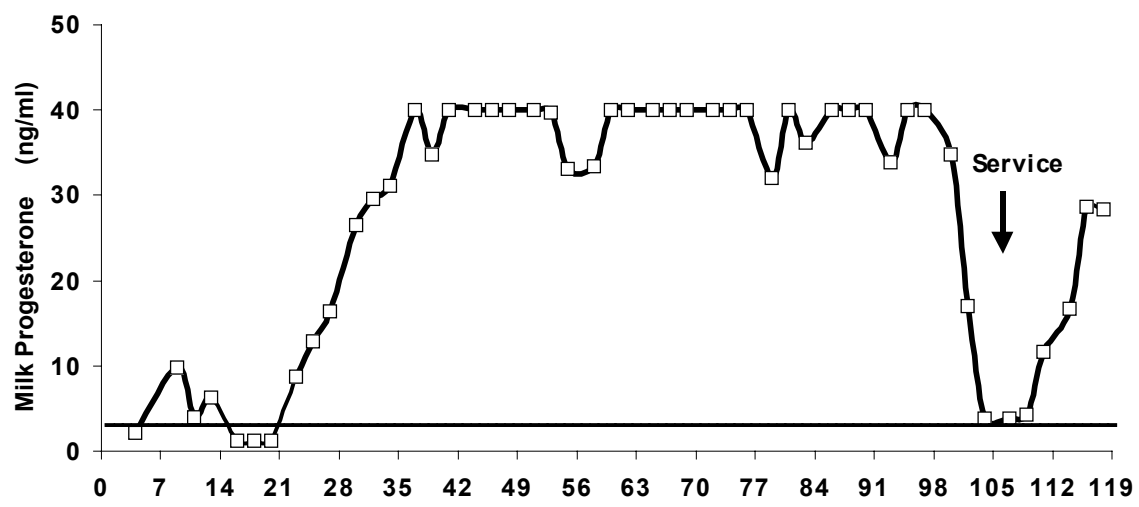

Figure 1 Examples of milk progesterone profiles: (A) normal, (B) DOV1 and (C) PCL1 categories in first lactation dairy cows. See text for further explanation.

glucose (Trinder; Sigma) and a kinetic assay for NEFA (Wako NEFA C test kit; Wako Chemicals GmbH, Neuss, Germany). For glucose, the inter- and intra-assay coefficients of variation were $7 \cdot 9 \%$ and $0.7 \%$ respectively. For NEFA, the inter- and intra-assay coefficients of variation were $8 \cdot 1 \%$ and $7 \cdot 9 \%$ respectively.

Progesterone was analysed in whole milk samples using the method of Bulman \& Lamming (1978) and in plasma following diethyl ether extraction using the method of Wathes et al. (1986). The progesterone antibody was a kind gift from Dr MJ Sauer, Veterinary Laboratory
Agency, Addlestone, Surrey, UK. The milk progesterone detection limit was $2 \mathrm{ng} / \mathrm{ml}$ and the inter- and intra-assay coefficients of variation were $9 \cdot 7 \%$ and $4 \cdot 2 \%$ respectively. The plasma progesterone inter- and intra-assay coefficients of variation were $12 \cdot 9 \%$ and $5 \cdot 2 \%$ respectively and the mean recovery was $73 \cdot 1 \%$.

\section{Statistical analyses}

Pulse analysis for the pre-challenge GH samples was performed on the Munro computer programme 
(MRC, Edinburgh, UK; Merriam \& Wachter 1982). All other statistical tests were performed with SPSS statistical software, version 11.5 (Chicago, IL, USA). All values are means \pm S.E.M. Animals were assigned to groups according to first lactation progesterone profile category (normal, DOV1 or PCL1) as described in the Materials and Methods. GH pulse parameters in the fed and fasted serial bleed sessions between progesterone profile groups were analysed by ANOVA and non-parametric tests. Areas under the curve (AUC) for GH, IGF-I and glucose were estimated using a linear trapezoidal equation. Plasma IGF-I, insulin and metabolite concentrations were transformed to obtain errors that were approximately normally distributed. Repeated measures ANOVA with posthoc LSD tests were used to analyse plasma GH, IGF-I, insulin, glucose and NEFA concentrations for the groups of animals with different progesterone profiles. Age and body weight at the time of the serial bleed (also birth weight, liveweight gain from birth, age and weight at puberty) were included as covariates in the repeated measures design but no significant correlations were found between any of the covariates and the dependent variable. Pearson's correlation analysis was used to determine the relationships between hormones or metabolites at the time of the serial bleed and the first lactation. Paired $t$-tests were used to compare IGF-I concentrations on the day of the GRF challenge and the day after. ANOVA with posthoc LSD tests were used for metabolites at specific time-points.

\section{Results}

\section{Fertility and production parameters}

The mean 305-day first lactation milk yield of the cows in this study was $7384 \pm 214 \mathrm{~kg}$ (range 3954-9038 kg) with a mean peak yield of $34 \pm 0 \cdot 8 \mathrm{~kg} /$ day occurring at mean week $10 \pm 0 \cdot 6$ after calving. Further details of production, metabolic and fertility parameters of these cows during their first lactation have been published separately (Taylor et al. 2003). Of the 32 heifers included in the present study, 17 had normal profiles, nine had DOV1 profiles and six had PCL1 profiles as defined in the Materials and Methods (Fig. 1). The DOV1 animals had significantly $(P<0 \cdot 001)$ longer intervals to first progesterone rise ( $71 \pm 8$ days of normal: $17 \pm 1 \cdot 7$ days; PCL1: $19 \pm$ 1.7 days). The length of the first luteal phase in the PCL1 animals was $46 \pm 11 \cdot 3$ days compared with $16 \pm 0 \cdot 8$ days in the normal profile cows.

\section{Prepuberty}

The prepubertal concentrations of metabolic hormones and metabolites in these same animals measured at 6 months of age (GH, 3-47 ng/ml; IGF-I, 110-284 ng/ $\mathrm{ml}$; insulin, fasted $0 \cdot 2-0.97 \mathrm{ng} / \mathrm{ml}$, fed $0.2-2.39 \mathrm{ng} / \mathrm{ml}$; glucose, fasted $3 \cdot 8-6 \cdot 3 \mathrm{mmol} / \mathrm{l}$, fed $4 \cdot 0-6 \cdot 1 \mathrm{mmol} / \mathrm{l}$; NEFA, fasted $29-447 \mu \mathrm{mol} / 1$, fed $20-85 \mu \mathrm{mol} / \mathrm{l}$ ) were within the ranges reported for Holstein calves of a similar age in previous studies (Lapierre et al. 1992, Govoni et al. 2002). No significant associations were found between the physical parameters measured at 6 months of age (weight, height, girth, body condition score (BCS), liveweight gain from birth) and the hormone or metabolite concentrations measured at the same time.

\section{Puberty}

The calves reached puberty at approximately 9 months of age, about 3.5 months after the metabolic measurements were taken. The physical attributes of the calves when they reached puberty are shown in Table 1 . There was a positive correlation $(r=0 \cdot 67, n=32, P<0 \cdot 001)$ between age and body weight at puberty. The BCS at which the calves reached puberty was positively related to the following parameters measured at 6 months $(n=32$ in each case): body weight $(r=0.50, P=0.003)$, girth $(r=0.52$, $P<0.002)$ and NEFA concentrations during the fed period of the prepubertal serial bleed $(r=0.56$ to 0.36 , $P=0 \cdot 001$ to $0 \cdot 047)$. The BCS at puberty was negatively related to $\mathrm{GH}$ parameters measured during the fasted period of the serial bleed session (mean GH nadir $r=-0.50, P<0.004$; measured GH level $r=-0 \cdot 45$, $P<0.011)$ and with glucose at time-points throughout the day $(-0.60$ to $-0.39, P<0.001$ to 0.03$)$.

Puberty parameters (age, body weight, BCS) were not associated with first lactation fertility parameters (body weight at calving, calf weight, days to first progesterone rise, calving to conception interval, services per conception or progesterone profile classification).

\section{Prepubertal hormone and metabolite concentrations in relation} to subsequent progesterone profiles

The prepubertal calf hormone data from the 10-h serial bleeds were then analysed according to whether the animals had normal, DOV1 or PCL1 progesterone profiles in their first lactation.

Endogenous GH Examples of the GH pulsatile release pattern from the different progesterone profiles are shown in Fig. 2. Analysis of the GH pulsatile release pattern during the fasted period (0800-1200 h) suggested a tendency $(P=0 \cdot 08$, non-parametric) for a lower number of $\mathrm{GH}$ peaks in DOV1 animals and correspondingly a tendency for a larger pulse interval and area (Fig. 2B and Table 2). In the fed period (1200-1600 h) GH pulse amplitude was significantly $(P=0 \cdot 04)$ higher in the PCL1 than the normal animals (Fig. 2A and $\mathrm{C}$ and Table 2) and the pulse areas tended $(P<0 \cdot 1)$ to be highest in the DOV1 and PCL1 animals in comparison with the normal profile cows. 


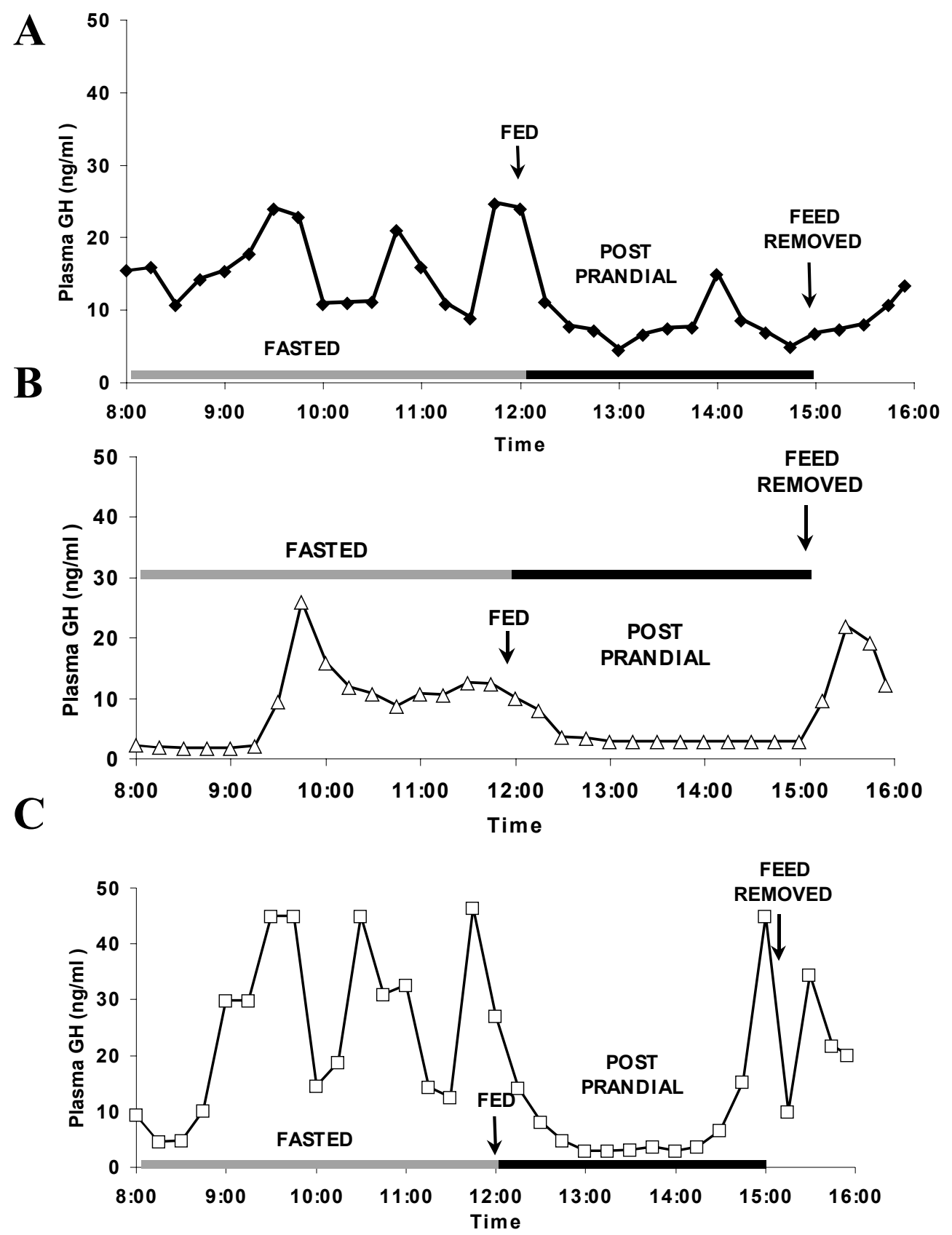

Figure 2 Examples of endogenous plasma GH profiles during the first $8 \mathrm{~h}$ of a serial bleed. Calves were fed following collection of the $1200 \mathrm{~h}$ plasma sample and their feed was removed at $1500 \mathrm{~h}$. A GRF challenge was given at $1600 \mathrm{~h}$ (see Fig. 3). Fasted period (shaded bars, fed period (solid bars). The animals were categorized according to their milk progesterone profiles following their first calving: (A) normal, (B) DOV1 and (C) PCL1 profile first lactation dairy cows.

GH challenge profiles Examples of individual GH challenge response profiles $(1605-1800 \mathrm{~h})$ of normal, DOV1 and PCL1 progesterone profile category animals are shown in Fig. 3. Neither the peak GH level reached nor the GH AUC differed according to progesterone profile category (Table 3 ).
IGF-I Throughout the whole prepubertal serial bleed session, PCL1 animals had significantly higher concentrations of IGF-I than the DOV1 animals $\left(\mathrm{F}_{(1,13)}=8 \cdot 195 ; P=0 \cdot 013\right.$, partial eta ${ }^{2}=0 \cdot 39$ (where partial $\mathrm{eta}^{2}$ is an estimate of the degree of association for the sample); Fig. 4A). On the day following the GRF 
Table 2 Endogenous GH parameters in prepubertal calves during a fasted ( $4 \mathrm{~h}$ ) and fed ( $3 \mathrm{~h} 55 \mathrm{~min}$ ) serial bleed session. Animals were categorised according to the progesterone profiles in their first lactation (means \pm S.E.M.)

\begin{tabular}{|c|c|c|c|c|c|c|}
\hline & $\begin{array}{l}\text { No. of } \\
\text { GH peaks }\end{array}$ & $\begin{array}{l}\text { Pulse interval } \\
\text { (min) }\end{array}$ & $\begin{array}{l}\text { Pulse amplitude } \\
(\mathrm{ng} / \mathrm{ml})\end{array}$ & $\begin{array}{l}\text { Pulse area } \\
\left(\mathrm{mm}^{2}\right)\end{array}$ & $\begin{array}{l}\text { Nadir } \\
(\mathrm{ng} / \mathrm{ml})\end{array}$ & $\begin{array}{l}\text { Measured level } \\
(\mathrm{ng} / \mathrm{ml})\end{array}$ \\
\hline \multicolumn{7}{|l|}{ Fasted } \\
\hline Normal $(n=17)$ & $2 \cdot 5 \pm 0 \cdot 15^{\mathrm{c}}$ & $92 \pm 11 \cdot 1^{d}$ & $13.9 \pm 1.59$ & $454 \pm 63 \cdot 5^{d}$ & $10 \cdot 1 \pm 0.99$ & $16 \pm 1 \cdot 4$ \\
\hline DOV1 $(n=9)$ & $2 \cdot 2 \pm 0 \cdot 32^{\mathrm{d}}$ & $116 \pm 23 \cdot 9^{c}$ & $18 \cdot 1 \pm 2 \cdot 92$ & $549 \pm 99 \cdot 9^{c}$ & $8 \cdot 2 \pm 1 \cdot 22$ & $14 \pm 1 \cdot 6$ \\
\hline $\operatorname{PCL} 1(n=6)$ & $3 \cdot 0 \pm 0 \cdot 00$ & $71 \pm 6 \cdot 4$ & $16 \cdot 9 \pm 3 \cdot 43$ & $450 \pm 62 \cdot 7$ & $8 \cdot 5 \pm 0 \cdot 82$ & $15 \pm 2 \cdot 3$ \\
\hline \multicolumn{7}{|l|}{ Fed } \\
\hline Normal $(n=17)$ & $1 \cdot 4 \pm 0 \cdot 19$ & $162 \pm 18 \cdot 0$ & $7 \cdot 7 \pm 1 \cdot 45^{\mathrm{b}}$ & $213 \pm 36 \cdot 4^{d}$ & $4 \cdot 7 \pm 0 \cdot 36$ & $8 \pm 0.6$ \\
\hline DOV1 $(n=9)$ & $1 \cdot 6 \pm 0 \cdot 24$ & $169 \pm 21 \cdot 4$ & $11 \cdot 6 \pm 1 \cdot 81$ & $382 \pm 73 \cdot 6^{c}$ & $4 \cdot 0 \pm 0 \cdot 47$ & $7 \pm 0 \cdot 8$ \\
\hline PCL1 $(n=6)$ & $1 \cdot 2 \pm 0 \cdot 48$ & $172 \pm 30 \cdot 6$ & $18 \cdot 3 \pm 7 \cdot 86^{\mathrm{a}}$ & $327 \pm 121 \cdot 1^{\mathrm{c}}$ & $3 \cdot 9 \pm 0 \cdot 72$ & $8 \pm 1 \cdot 2$ \\
\hline
\end{tabular}

Means in columns with different superscripts differ $(a>b, P<0 \cdot 05 ; c>d, P<0 \cdot 1)$.

challenge and stimulated GH increase, only the normal animals showed a significant IGF-I increase $(P<0 \cdot 001$, paired $t$-test; Fig. 4A). On day 2, the IGF-I concentrations of the DOV1 animals were thus significantly lower than in either the normal or the PCL1 animals $(P<0 \cdot 05$; Fig. 4A).

Insulin, glucose and NEFA Insulin concentrations in all animals increased after feeding as expected and there were no differences in concentrations between the different progesterone profile category groups (Fig. 5A). There was a significant $(P<0 \cdot 001)$ profile by time interaction in glucose: in the normal and PCL1 profile animals the glucose concentrations fell in response to the insulin rise but there was no decrease in glucose in the DOV1 animals, such that their glucose levels remained significantly higher after feeding $\left(\mathrm{F}_{(2,29)}=4 \cdot 031 ; \quad P=0 \cdot 029\right.$, partial eta ${ }^{2}=0 \cdot 22$; Fig. 6 A). NEFA concentrations fell after feeding and were similar between normal and abnormal profile category primiparous cows (Fig. 5B).

\section{Associations between prepubertal and first lactation hormone concentrations}

The IGF-I concentration measured during the prepubertal period (Fig. 4A) was significantly related to the weekly IGF-I concentrations measured during the start of the first lactation (Fig. 4B). To simplify analysis, the first lactation IGF-I AUC in individual animals was calculated over weeks 1 to 7 . We have previously shown that IGF-I concentrations during this period are related to subsequent fertility (Pushpakumara et al. 2003). This AUC concentration was positively correlated with the individual prepubertal IGF-I concentrations both before $(0800 \mathrm{~h}$, $r=0.476, P=0.006$; Fig. 4C) and after feeding (1555 h, $r=0.428, P=0.015 ; 1800 \mathrm{~h}, r=0 \cdot 395, P=0.025 ; n=32)$.

In contrast, the glucose concentration measured both before and after feeding during the prepubertal period (Fig. 6A) was negatively related to the glucose concentrations measured during the start of the first lactation (Fig. 6B). Relationships between the glucose AUC from
A

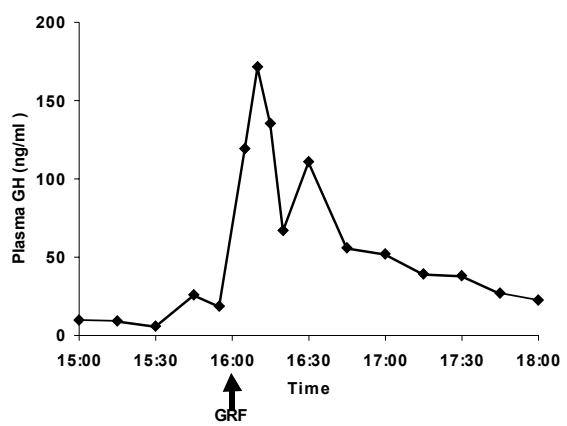

B

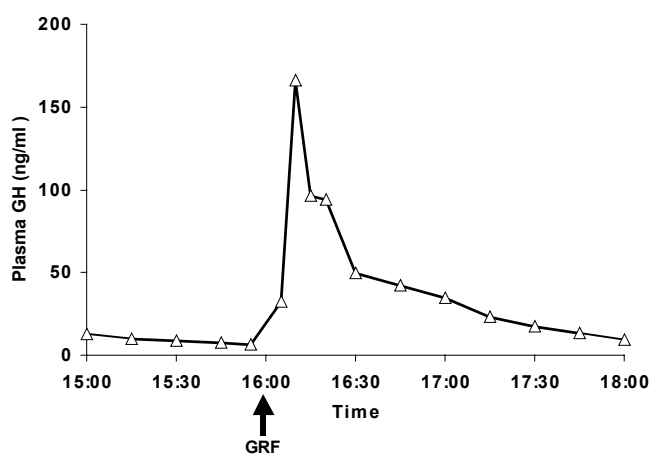

C

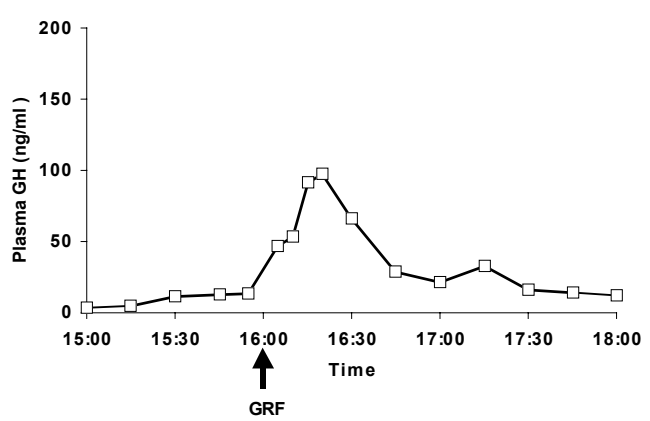

Figure 3 Examples of stimulated plasma GH profiles following a GRF challenge given at $1600 \mathrm{~h}$. The animals were categorized according to their milk progesterone profiles following their first calving: (A) normal, (B) DOV1 and (C) PCL1 profile first lactation dairy cows. 
Table 3 Stimulated GH response parameters in prepubertal calves according to the progesterone profiles in their first lactation (means \pm S.E.M.)

weeks 3 to 5 post-calving and the prepubertal glucose concentrations at various times were as follows: $0800 \mathrm{~h}$, $r=-0.39, \quad P=0.029 ; \quad 1000 \mathrm{~h}, \quad r=-0 \cdot 49, \quad P=0.004$; $1200 \mathrm{~h}, \quad r=-0.55, \quad P=0.001 ; \quad 1400 \mathrm{~h}, \quad r=-0.59$, $P<0 \cdot 001 ; 1800 \mathrm{~h}, r=-0 \cdot 42, P=0 \cdot 018 ; n=32$ in each case. An example of this relationship is illustrated in Fig. 6C.

No associations were found between prepubertal and first lactation insulin or NEFA concentrations. GH was not measured during the first lactation.

\section{Discussion}

Many dairy cows experience irregularities in their progesterone profiles, which contribute to poor fertility (Bulman \& Wood 1980, Royal et al. 2000). The incidence of such cycle irregularities is higher in cows which have been genetically selected to produce more milk (Taylor 2001). In addition to a direct effect of the somatotrophic axis on milk production it is also possible that the changes to the somatotrophic axis, which have occurred during selection for yield, may act directly on the reproductive system to predispose animals to poor fertility. The two most common problems are a prolonged interval to first ovulation and persistent luteal phases. Delayed resumption of cyclicity may occur in response to the negative energy balance, which occurs in early lactation (Beam \& Butler 1999, Beever et al. 2001). The incidence of PCL profiles in the UK has increased from 13\% in 1975-1982 to 44\% in 1998 (Lamming \& Royal 2001) and risk factors for PCL include a difficult calving, early resumption of cyclicity, uterine infection (Opsomer et al. 2000) and heat stress (Lucy 2001). In this study we have shown that (1) IGF-I and glucose concentrations in prepubertal animals were related to their post-calving concentrations, (2) heifers which later showed abnormal ovarian cyclicity during their first lactation had measurably different metabolic profiles as juveniles and (3) measurements of metabolic status at 6 months were related to the BCS at which the heifers attained puberty.

Dairy cows in peak lactation have a metabolic profile that is characterized by an increased amplitude and frequency of GH secretion (Hart et al. 1978, Kunz et al.
A

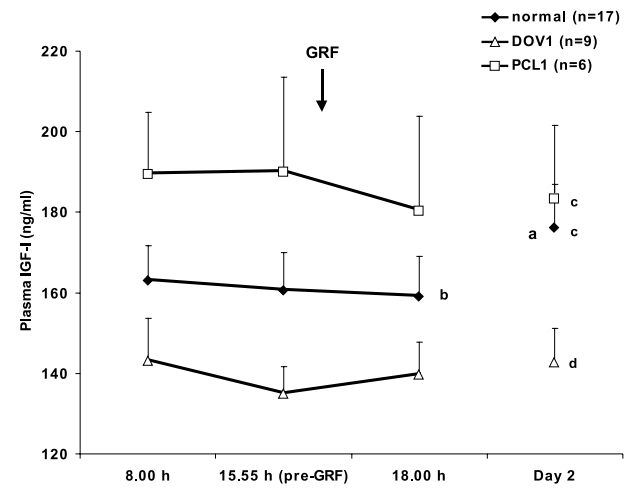

B

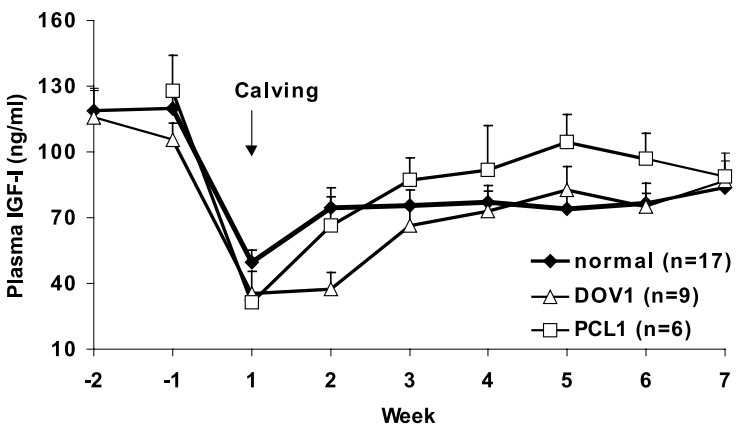

C

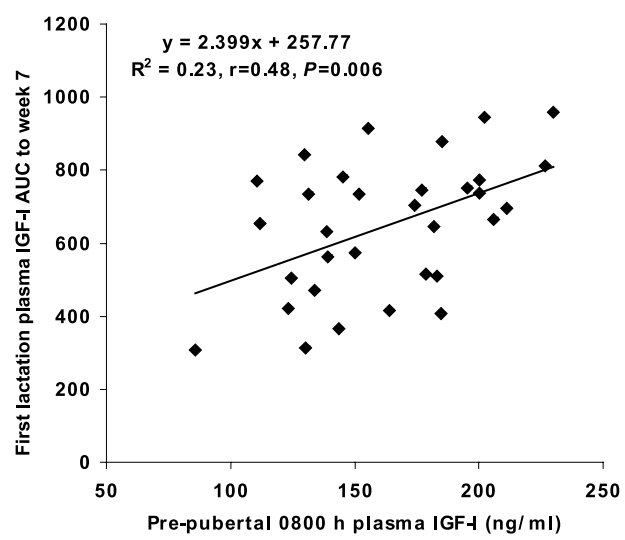

Figure 4 Plasma IGF-I concentrations with animals categorized according to their milk progesterone profiles following their first calving (normal, DOV1, PCL1; values are expressed as means \pm S.E.M.). (A) Prior to and following a GRF challenge in prepubertal heifer dairy calves, PCL1 animals had significantly $(P<0.05)$ higher IGF-I than DOV1 animals over the 2 days. IGF-I concentrations increased from day 1 to 2 in normal profile animals, but not in DOV1 or PCL cows $(a>b, P<0.001 ; c>d$, $P<0 \cdot 05)$. (B) During their first lactation, IGF-I concentrations decreased to lower levels in the first 2 weeks after calving in DOV 1 compared with normal profile cows $(P<0 \cdot 05)$. (C) Correlation analysis found that IGF-I concentrations within individual cows were positively related between the prepubertal and first lactation time-periods.

1985), hepatic GH resistance due to a down-regulation of GH receptors 1A (Kobayashi et al. 1999), low IGF-I and insulin concentrations (Pushpakumara et al. 2003) and 
A

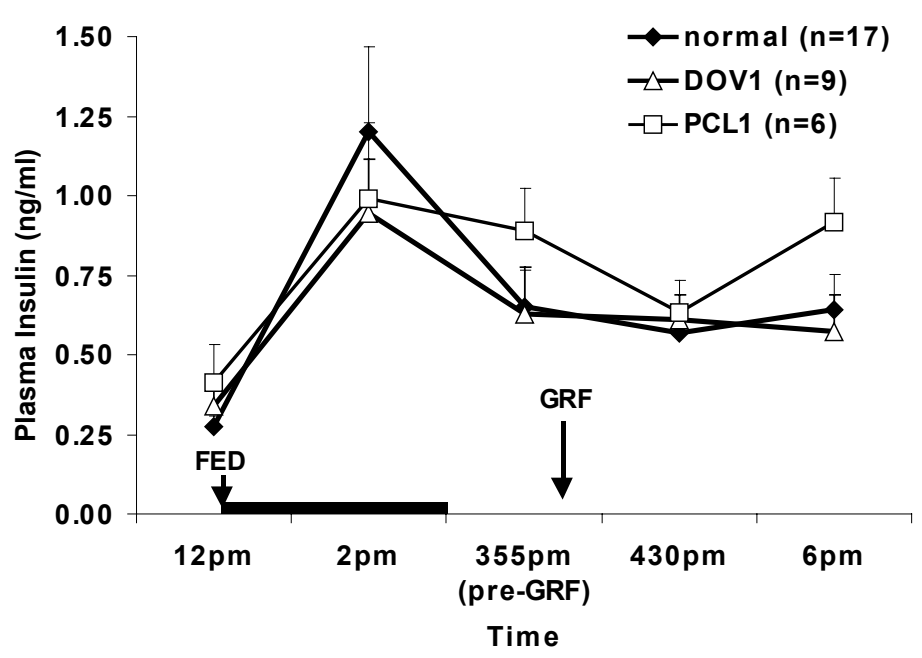

B

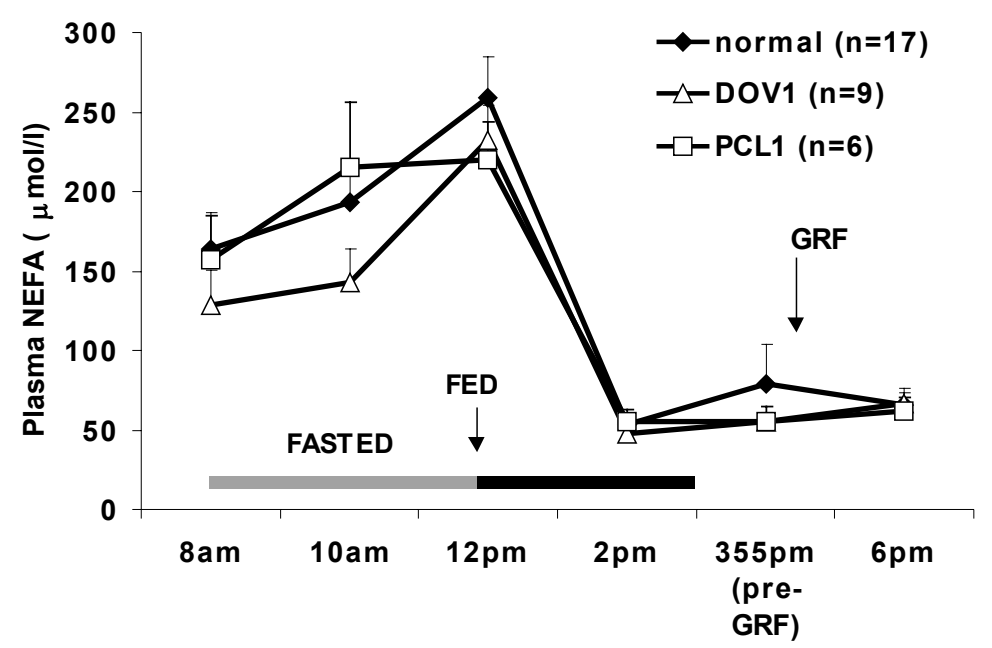

Figure 5 Plasma (A) insulin and (B) NEFA concentrations prior to and following a GRF challenge in prepubertal heifer dairy calves $(n=32)$ that were subsequently monitored until the end of their first lactation and the data analysed according to their actual ovarian function. Values are expressed as means \pm S.E.M. There were no differences in insulin or NEFA concentrations between the different profile groups.

decreased tissue utilization of glucose (Bell \& Bauman 1997). This endocrine situation leads to body condition loss (Butler 2000, Taylor et al. 2003). We and others have reported previously that individual cows differ in the extent to which they mobilize their body reserves (Hattan et al. 2001) and that excessive loss of condition impairs fertility (Butler 2000, Wathes et al. 2001, Taylor et al. 2003). The genetic or developmental background of the individual cow may therefore determine its predisposition to developing such extreme metabolic profiles.
In this study, heifers that achieved puberty at a lower BCS had a higher GH nadir and measured level in the fasted period coupled with higher glucose concentrations. The negative association found between prepubertal and first lactation glucose concentrations was unexpected. The regulation of glucose homeostasis varies during lactation when glucose uptake by the mammary gland is largely independent of insulin. Whatever the underlying mechanism, the lower circulating glucose concentrations during lactation could have a detrimental effect on ovarian function (see later). 
A

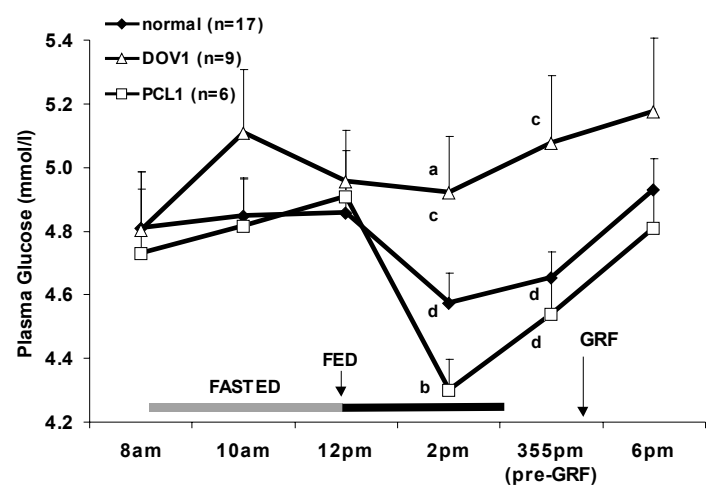

B
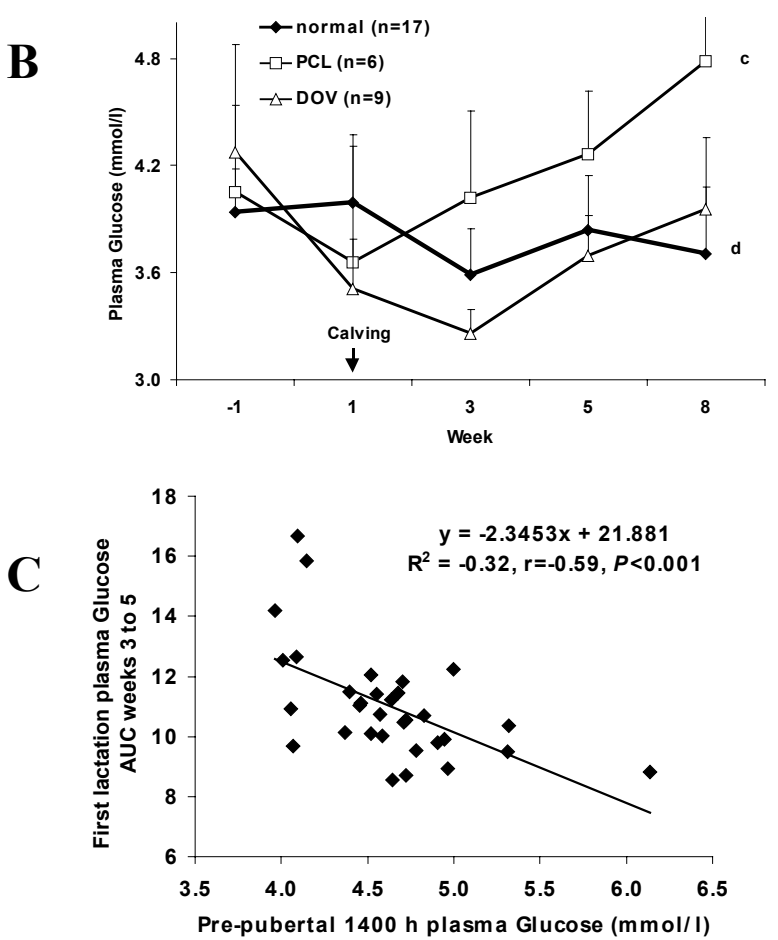

Figure 6 Plasma glucose concentrations with animals categorized according to their milk progesterone profiles following their first calving (normal, DOV1, PCL1; values are expressed as means \pm S.E.M.). (A) Prior to and following a GRF challenge in prepubertal heifer dairy calves, glucose concentrations were highest after feeding in DOV1 animals $(a>b, P<0.01 ; c>d$, $P<0.05)$. (B) During their first lactation, PCL1 animals had significantly $(P=0.026)$ higher glucose at the start of the service period (week 8 ) than normal profile cows (c $>d, P<0 \cdot 05$ ). (C) Regression analysis to show that glucose concentrations within individual cows were negatively related between the prepubertal and first lactation time-periods.

The most common progesterone profile associated with impaired fertility in primiparous cows was delayed ovulation (DOV1) (Taylor et al. 2003). When DOV1 cows were compared with cows that ovulated again within 6 weeks of calving, a number of differences were apparent. These included lower dry matter intakes, low body weights at calving or more sustained BCS losses throughout the early post-partum period, lower plasma IGF-I and/or insulin concentrations post-calving and reduced fertility compared with normal profile cows (Taylor et al. 2003). Milk yield was, however, not different between the normal and DOV1 cows, although the DOV1 cows did produce a higher milk fat content. It is thought that the development of a DOV1 profile is caused by the low IGF-I and insulin concentrations acting at the level of the hypothalamic-pituitary axis to inhibit LH pulsatility (Wiltbank et al. 2002) and at the ovary to prevent follicular maturation and thus ovulation (Beam \& Butler 1999, Wathes et al. 2003).

In the present study, we have shown that the DOV1 animals, as calves, had the lowest IGF-I concentrations and tended to have fewer, larger GH pulses during fasting. In early lactation, when GH concentrations are high, their possibly predetermined lower IGF-I concentrations may have exerted less negative feedback on GH release, thus allowing more mobilization of adipose reserves to sustain yield. This was followed by greater BCS losses with the resultant detrimental effect on reproductive function. Furthermore, the DOV1 calves did not show a significant fall in glucose following a post-prandial insulin increase. This suggests that they were more insulin resistant than the normal profile calves, another characteristic which could impact on fertility by reducing glucose availability to the ovary (Rabiee et al. 1999) while at the same time maintaining glucose transfer to the mammary gland, which is largely independent of insulin (McGuire et al. 1995b).

The homeostatic adjustments caused by the drain of glucose to the mammary gland may be causing the high yielding dairy cow to have a 'diabetic-like' metabolic profile early in lactation, but from which they later recover. There may thus be some similarities between the DOV1 condition and insulin-dependent diabetes mellitus (IDDM) in humans in which the GH-IGF-I-insulin axis is also affected. IDDM is associated with an increased amplitude and frequency of GH secretion (Giustina \& Veldhuis 1998), prolonged GH clearance (Dunger et al. 1993), low GH-binding protein, and reduced insulin and IGF-I concentrations (Halldin et al. 2000). Disturbances in these inter-relationships are thought to be responsible for impaired glycaemic control in IDDM adolescent girls (Halldin et al. 2000). However, glucose concentrations in IDDM humans are high whereas those in lactating cows are low, due to the removal of glucose by the mammary gland.

Although the reason for the increased incidence of PCL profiles in recent years is unknown, we have some evidence that it may be related to higher yield (Taylor 2001). In this study, heifers which later developed a PCL1 profile had a significantly larger GH pulse amplitude and pulse area than the normal animals in the fed period (i.e. an altered response to feeding) when studied as calves, and 
their IGF-I concentrations were also higher. When these animals were studied in their first lactation, their metabolic and fertility parameters were similar to normal animals but they had a higher feed intake than the DOV1 animals (Taylor et al. 2003). Hence PCL1 cows may have elevated $\mathrm{GH}$ concentrations as a consequence of selection for yield but, perhaps more importantly, their IGF-I concentrations were also increased in line with $\mathrm{GH}$, indicating that they did not become GH resistant and these cows did not suffer major post-partum body condition losses. Thus the PCL cows maintained their yield with greater dry matter intake, compared with DOV1 cows, without major adverse consequences for the reproductive system. The endocrine profile of high GH levels may, however, be responsible for the extension of the luteal phase, as GH has been shown to be luteotrophic in vitro (Liebermann \& Schams 1994, Wathes et al. 1995) and some studies have reported that administration of bovine somatotrophin to lactating cows can prolong the luteal phase (Schemm et al. 1990, Gallo \& Block 1991, Lucy et al. 1994), although this effect was not seen in 1-year-old heifers (Yung et al. 1996).

This study has also shown differences in the pattern of $\mathrm{GH}$ secretion between the groups of animals and in response to feeding. GH secretion is controlled by complex feedback and feedforward neuroregulation (Giustina \& Veldhuis 1998) but the responses to feeding are not well understood. GH secretagogue challenges have previously been used as an indicator of genetic merit for milk production in prepubertal dairy bulls (Løvendahl et al. 1991a) as they are easier to measure than the natural pulsatile GH secretion pattern. However, in this study the response to the GRF challenge was not significantly altered between groups of female calves, suggesting that this test would not be useful in predicting fertility. Our results suggest that measurement of IGF-I prepubertally may be of more use in this respect.

In conclusion, we have shown here for the first time that cows which suffer from irregular progesterone profiles during lactation have differences in aspects of their somatotrophic axis as juveniles. These data suggest that such animals may be predisposed to develop fertility problems in later life and also raise the possibility of improved selection criteria for heifers which are more likely to be able to cope with the requirement of remaining fertile whilst still producing a high milk yield.

\section{Acknowledgements}

The authors are grateful to the staff at the Animal Production Research Unit and the Centre for Dairy Research, University of Reading for the care of the animals, to Professor R Scaramuzzi for performing the GH pulse analysis and to Mrs Ailiang Zhang for analysis of some samples.

\section{Funding}

This work was funded by the Milk Development Council.

\section{References}

Adam CL, Gadd TS, Findlay PA \& Wathes DC 2000 IGF-I stimulation of luteinizing hormone secretion, IGF-binding proteins (IGFBPs) and expression of mRNAs for IGFs, IGF receptors and IGFBPs in the ovine pituitary gland. Journal of Endocrinology 166 247-254.

Auchtung TL, Buchanan DS, Lents CA, Barao SM \& Dahl GE 2001 Growth hormone response to growth hormone-releasing hormone in beef cows divergently selected for milk production. Journal of Animal Science 79 1295-1300.

Beam SW \& Butler WR 1999 Effects of energy balance on follicular development and first ovulation in postpartum dairy cows. Journal of Reproduction and Fertility 54 (Suppl) 411-424.

Beever DE, Hattan A, Reynolds CK \& Cammell SB 2001 Nutrient supply to high-yielding dairy cows. In Fertility in the High-Producing Dairy Cow. British Society of Animal Science Occasional Publication No. 26 119-131.

Bell AW \& Bauman DE 1997 Adaptations of glucose metabolism during pregnancy and lactation. Journal of Mammary Gland Biology and Neoplasia 2 265-278.

Bonczek RR, Young CW, Wheaton JE \& Miller KP 1988 Response of somatotropin, insulin, prolactin and thyroxine to selection for milk yield in Holsteins. Journal of Dairy Science 71 2470-2479.

Bulman DC \& Lamming GE 1978 Milk progesterone levels in relation to conception, repeat breeding and factors influencing acyclicity in dairy cows. Journal of Reproduction and Fertility 54 447-458.

Bulman DC \& Wood PDP 1980 Abnormal patterns of ovarian activity in dairy cows and their relationships with reproductive performance. Animal Production 30 177-188.

Butler WR 2000 Nutritional interactions with reproductive performance in dairy cattle. Animal Reproduction Science 60-61 449-457.

Butler WR \& Smith RD 1989 Interrelationships between energy balance and postpartum reproductive function in dairy cattle. Journal of Dairy Science 72 767-783.

Chase CC Jr, Kirby CJ, Hammond AC, Olson TA \& Lucy MC 1998 Patterns of ovarian growth and development in cattle with a growth hormone receptor deficiency. Journal of Animal Science 76 212-219.

Childs GV 2000 Growth hormone cells as co-gonadotropes: partners in the regulation of the reproductive system. Trends in Endocrinology and Metabolism 11 168-175.

Chilliard Y 1999 Metabolic adaptations and nutrient partitioning in the lactating animal. In Biology of Lactation, pp 503-552. Eds J Martinet, L-M Houdebine \& HH Head. Paris: INRA.

Dunger DB, Cheetham TD, Holly JM \& Matthews DR 1993 Does recombinant insulin-like growth factor I have a role in the treatment of insulin-dependent diabetes mellitus during adolescence? Acta Paediatrica 388 (Suppl) 49-53.

Etherton TD \& Bauman DE 1998 Biology of somatotropin in growth and lactation of domestic animals. Physiological Reviews 78 745-761.

Gallo GF \& Block E 1991 Effects of recombinant bovine somatotropin on hypophyseal and ovarian functions of lactating dairy cows. Canadian Journal of Animal Science 71 343-353.

Giustina A \& Veldhuis JD 1998 Pathophysiology of the neuroregulation of growth hormone secretion in experimental animals and the human. Endocrine Reviews 19 717-797.

Gluckman PD, Breier BH \& Davis SR 1987 Physiology of the somatotropic axis with particular reference to the ruminant. Symposium: Growth Hormone and Biotechnology. Journal of Dairy Science 70 442-466. 
Govoni KE, Tian C, Kazmer GW, Taneja M, Enright BP, Rivard AL, Yang Z \& Zinn SA 2002 Age-related changes of the somatotrophic axis in cloned Holstein calves. Biology of Reproduction 66 1293-1298.

Halldin MU, Hagenäs L, Tuvemo T \& Gustafsson J 2000 Profound changes in the GH-IGF-I system in adolescent girls with IDDM: can IGFBP1 be used to reflect overall glucose regulation? Pediatric Diabetes 1 121-130.

Hart IC, Flux DS, Andrews P \& McNeilly AS 1975 Radioimmunoassay for ovine and caprine growth hormone: its application to the measurement of basal circulating levels of growth hormone in the goat. Hormone and Metabolic Research 7 35-40.

Hart IC, Flux DS, Andrews P \& McNeilly AS 1978 Endocrine control of energy metabolism in the cow: comparison of the levels of hormones (prolactin, growth hormone, insulin and thyroxine) and metabolites in the plasma of high- and low-yielding cattle at various stages of lactation. Journal of Endocrinology 77 333-345.

Hattan AJ, Beever DE, Cammell JD \& Sutton JD 2001 Energy metabolism in high yielding dairy cows during early lactation. In Energy Metabolism in Animals, pp 325-328. Eds A Chwalibog \& K Jakobsen. Wageningen: European Association for Animal Production Publication No. 103.

Kobayashi Y, Boyd CK, Bracken CJ, Lamberson WR, Keisler DH \& Lucy MC 1999 Reduced growth hormone receptor (GHR) messenger ribonucleic acid in liver of periparturient cattle is caused by a specific down-regulation of GHR 1A that is associated with decreased insulin-like growth factor I. Endocrinology 140 3947-3954.

Kunz PL, Blum JW, Hart IC, Bickel H \& Landis J 1985 Effects of different energy intakes before and after calving on food intake, performance and blood hormones and metabolites in dairy cows. Animal Production 40 219-231.

Lamming GE \& Darwash AO 1998 The use of milk progesterone profiles to characterise components of subfertility in milked dairy cows. Animal Reproduction Science 52 175-190.

Lamming GE \& Royal MD 2001 Ovarian hormone patterns and subfertility in dairy cows. In Fertility in the High-Producing Dairy Cow. British Society of Animal Science Occasional Publication No. 26 105-118.

Lamming GE, Darwash AO, Wathes DC \& Ball PJ 1998 The fertility of dairy cattle in the UK: current status and future research. Journal of the Royal Agricultural Society 159 82-93.

Lapierre H, Farmer C, Girard C \& Brazeau P 1992 Effect of age and intake on growth hormone kinetics in dairy heifers. Domestic Animal Endocrinology 9 199-207.

Leeuwenberg BR, Hudson NL, Moore LG, Hurst PR \& McNatty KP 1996 Peripheral and ovarian IGF-I concentrations during the ovine oestrous cycle. Journal of Endocrinology 148 281-289.

LeRoith D, Scavo L \& Butler A 2001 The somatomedin hypothesis: 2001. Endocrine Reviews 22 53-74.

Liebermann J \& Schams D 1994 Actions of somatotrophin on oxytocin and progesterone release from the microdialysed bovine corpus luteum in vitro. Journal of Endocrinology 143 243-250.

Løvendahl P, Angus KD \& Woolliams JA 1991a The effect of genetic selection for milk yield on the response to growth hormone secretagogues in immature cattle. Journal of Endocrinology 128 419-424.

Løvendahl P, Woolliams JA \& Sinnett-Smith PA $1991 b$ Response of growth hormone to various doses of growth hormone releasing factor and thyrotropin releasing hormone administered separately and in combination to dairy calves. Canadian Journal of Animal Science 71 1045-1052.

Lucy MC 2001 Reproductive loss in high-producing dairy cattle: where will it end? Journal of Dairy Science 84 1277-1293.

Lucy MC, Byatt JC, Curran TL, Curran DF \& Collier RJ 1994 Placental lactogen and somatotropin: hormone binding to the corpus luteum and effects on the growth and functions of the ovary in heifers. Biology of Reproduction 50 1136-1144.
Lucy MC, Bilby CR, Kirby CJ, Yuan W \& Boyd CK 1999 Role of growth hormone in development and maintenance of follicles and corpora lutea. Journal of Reproduction and Fertility 54 (Suppl) 49-59.

Lukes AJ, Barnes MA \& Pearson RE 1989 Response to selection for milk yield and metabolic challenges in primiparous dairy cows. Domestic Animal Endocrinology 6 287-298.

McArdle CA, Kohl C, Rieger K, Groner I \& Wehrenberg U 1991 Effects of gonadotropins, insulin and insulin-like growth factor I on ovarian oxytocin and progesterone production. Molecular and Cellular Endocrinology 78 211-220.

McGuire MA, Bauman DE, Dwyer DA \& Cohick WS 1995a Nutritional modulation of the somatotropin/insulin-like growth factor system: response to feed deprivation in lactating cows. Journal of Nutrition 125 493-502.

McGuire MA, Griinari JM, Dwyer DA \& Bauman DE $1995 b$ Role of insulin in the regulation of mammary synthesis of fat and protein. Journal of Dairy Science 78 816-824.

Merriam GR \& Wachter KW 1982 Algorithms for the study of episodic hormone secretion. American Journal of Physiology (Endocrinology and Metabolism 6) 243 E310-E318.

Opsomer G, Grohn YT, Hertl J, Coryn M, Deluyker H \& de Kruif A 2000 Risk factors for post partum ovarian dysfunction in high producing dairy cows in Belgium: a field study. Theriogenology 53 841-857.

Osgerby JC, Wathes DC, Howard D \& Gadd TS 2002 The effect of maternal undernutrition on ovine fetal growth. Journal of Endocrinology 173 131-141.

Perks CM, Peters AR \& Wathes DC 1999 Follicular and luteal expression of insulin-like growth factors I and II and the type 1 IGF receptor in the bovine ovary. Journal of Reproduction and Fertility 116 157-165.

Pushpakumara PGA, Gardner NH, Reynolds CK, Beever DE \& Wathes DC 2003 Relationships between transition period diet, metabolic parameters and fertility in lactating cows. Theriogenology $601165-1185$.

Rabiee AR, Lean IJ, Gooden JM \& Miller BG 1999 Relationships among metabolites influencing ovarian function in the dairy cow. Journal of Dairy Science 82 39-44.

Royal MD, Darwash AO, Flint APF, Webb R, Woolliams JA \& Lamming GE 2000 Declining fertility in dairy cattle: changes in traditional and endocrine parameters of fertility. Animal Science $\mathbf{7 0}$ 487-501.

Schemm SR, Deaver DR, Griel LC \& Muller LD 1990 Effects of recombinant bovine somatotropin on luteinizing hormone and ovarian function in lactating dairy cows. Biology of Reproduction 42 815-821.

Schoppee PD, Armstrong JD, Harvey RW, Whitacre MD, Felix A \& Campbell RM 1996 Immunization against growth hormone-releasing factor or chronic feed restriction initiated at $3 \cdot 5$ months of age reduces ovarian response to pulsatile administration of gonadotropin-releasing hormone at 6 months of age and delays onset of puberty in heifers. Biology of Reproduction 55 87-98.

Shingu H, Hodate K, Kushibiki S, Ueda Y, Watanabe A, Shinoda M \& Matsumoto M 2001 Profiles of growth hormone and insulin secretion, and glucose response to insulin in growing Japanese Black heifers (beef type): comparison with Holstein heifers (dairy type). Comparative Biochemistry and Physiology Part C 130 259-270.

Spicer LJ \& Echternkamp SE 1995 The ovarian insulin and insulin-like growth factor system with an emphasis on domestic animals. Domestic Animal Endocrinology 12 223-245.

Staples CR, Burke JM \& Thatcher WW 1998 Influence of supplemental fats on reproductive tissues and performance of lactating cows. Journal of Dairy Science 81 856-871.

Taylor VJ 2001The Growth Hormone (GH) and Insulin-Like Growth Factor (IGF) Axis in Relation to Fertility in High Yielding Dairy Cows. $\mathrm{PhD}$ thesis, Royal Veterinary College, University of London. 
Taylor VJ, Beever DE, Bryant MJ \& Wathes DC 2003 Metabolic profiles and progesterone cycles in first lactation dairy cows. Theriogenology 59 1661-1677.

Thissen J-P, Ketelslegers J-M \& Underwood LE 1994 Nutritional regulation of the insulin-like growth factors. Endocrine Reviews $\mathbf{1 5}$ 80-101.

Van den Berghe G, de Zegher F \& Bouillon R 1998 The somatotrophic axis in critical illness: effects of growth hormone secretagogues. Growth Hormone and IGF Research 8 (Suppl B) 153-155.

Wathes DC, Guldenaar SEF, Swann RW, Webb R, Porter DG \& Pickering BT 1986 A combined radioimmunoassay and immunocytochemical study of ovarian oxytocin production during the periovulatory period in the ewe. Journal of Reproduction and Fertility 78 167-183.

Wathes DC, Perks CM, Davis AJ \& Denning Kendall PA 1995 Regulation of insulin-like growth factor-I and progesterone synthesis by insulin and growth hormone in the ovine ovary. Biology of Reproduction 53 882-889.

Wathes DC, Beever DE, Cheng Z, Pushpakumara PGA \& Taylor VJ 2001 Life-time organisation and management of reproduction in the dairy cow. In Integrated Management Systems for Livestock Production. British Society of Animal Science Occasional Publication No. 28 59-69.

Wathes DC, Taylor VJ, Cheng Z \& Mann GE 2003 Follicle growth, corpus luteum function and their effects on embryo development in the post partum dairy cow. Reproduction in Domestic Ruminants $\mathbf{6 1}$ (Suppl) 219-237.

Webb R, Garnsworthy PC, Gong JG, Robinson RS \& Wathes DC 1999 Consequences for reproductive function of metabolic adaption to load. In Metabolic Stress in Dairy Cows. British Society of Animal Science Occasional Publication No. 24 99-112.

Wiltbank MC, Gumen A \& Sartori R 2002 Physiological classification of anovulatory conditions in cattle. Theriogenology 57 21-52.

Yung MC, VandeHaar MJ, Fogwell RL \& Sharma BK 1996 Effect of energy balance and somatotropin on insulin-like growth factor I in serum and on weight and progesterone of corpus luteum in heifers. Journal of Animal Science 74 2239-2244.

Received in final form 9 September 2003

Accepted 12 September 2003 